\title{
THE POSTGRADUATE
}

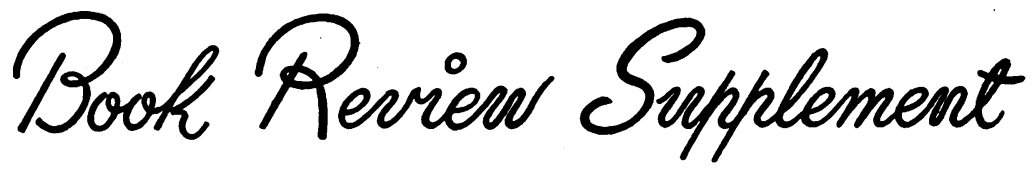

\section{THE LIFE AND WORK OF ASTLEY COOPER}

By R. C. Brock, M.S., F.R.C.S., F.A.C.S. Pp. viii +176 , with 15 illustrations. Edinburgh : E. \& S. Livingstone Ltd. 1952. zos.

This account of the life and work of Sir Astley Cooper is the first full biography of this great surgeon to be published for I09 years. The absence of a serious attempt to record his achievements before now is inexplicable. Why a biography of a pioneer of vascular surgery now appears from the pen of a pioneer of cardiovascular surgery is explained very simply and adequately in the author's preface. The similarity of their initial problems is evident in the pages of this history. Indeed, the words of Astley Cooper on the occasion he performed the first ligation of the human aorta, "Gentlemen, I have the pleasure of informing you that the aorta is now hooked upon my finger," may be heard in the theatre of Guy's Hospital today !

To many of the present generation Astley Cooper is vaguely remembered for his description of the anatomy of inguinal and femoral herniae and the suspensory ligaments of the breast, and this despite the fact that 130 years ago he was a surgeon of international repute and without a rival in his own country. He was, moreover, a man of considerable charm with characteristics and customs dear to the heart of any biographer. It is indeed remarkable that these qualities have not hitherto received the recognition they merit.

The author of this biography has made the most of his material and presented a most readable account. Besides recording Astley Cooper's achievements as surgeon, teacher and research worker which he was from first to last, Brock has succeeded in portraying the character of the man as it may have appeared to his contemporaries. The many quotations from the earlier biography by Astley Cooper's nephew, Bransby Cooper, present a vivid picture of the 18 th century professional scene. The practice of surgery in those days was not one to be undertaken by the faint-hearted. That Cooper possessed the necessary skill, sympathy and commanding presence is evident from this book. Yet in retrospect his greatest achievements were his contributions to surgical progress. His daily work and habits are well illustrated, as are details of many of his operating sessions. As already mentioned these are strangely topical. Brock has rightly stressed Cooper's success in applying the results of animal experiment and careful observation to the treatment of disease. This is exemplified by the introduction of ligation of the carotid and femoral arteries and of the aorta for aneurysm. The contributions to the anatomy of hernia were the outcome of years of dissection before breakfast. Brief accounts are included of the works on fractures and the anatomy of the testis and the breast. Undoubtedly much could be written on the achievements of a man who sterilized and used buried catgut 50 years before Lister.

Cooper was intimately connected with the formation of the Medical School at Guy's and with the events leading up to the division of the United Hospitals of St. Thomas's and Guy's into separate institutions. Details of medical politics of hiso time and reproductions of contemporary illustrations add to the general interest of the biography

It has been a source of sorrow to the reviewe that few biographies of British men of medicine compare in interest and detail with those of Osler and Cushing. In its way this life of Astley Cooper, though brief, does something towards remedying the deficiency. Though the author has written with an enthusiasm which will be communicated to most of his readers he has done no more than justice to the character of the man he portrays. An informative bibliography of Astley Cooper's publications as well as a list of references used by the author are included.

$$
\text { A.J.P.G. }
$$

\section{BACTERIA}

By K. A. BissetT, D.Sc., àssisted by F. W. Moore,

B.Sc. Pp. viii +123 , with 38 illustrations.

Edinburgh: E. \& S. Livingstone. 1952. 20 s.

In the preface the author hopes that this book will prove valuable to students of microbiology and research workers in the fields of industry, medicine and biochemistry. In this he appears to have been too ambitious, for he falls between two stoolsthe book is suitable for neither. Too much information is crammed into a small compass, which makes the book difficult to read and forces the author to treat contentious material in an uncritical and dogmatic fashion. For the research worker there are insufficient references.

The fundamental weakness of the book is that it is a vehicle for the author's proposed classification of bacteria based on their morphology and, as such, 